\title{
Spatial Variability in Groundwater Quality in Pundri block of Kaithal District, Haryana, India
}

\author{
Parveen Rathi", Ramprakash, Sanjay Kumar, Satyavan and Raman Sharma
}

CCS Haryana Agricultural University, Hisar-125004, Haryana, India

*Corresponding author

\begin{abstract}
A B S T R A C T
\section{Keywords}

Groundwater quality,

Survey, Electrical

conductivity,

Geographical information system, RSC, SAR

Article Info

Accepted:

15 January 2018

Available Online:

10 February 2018

Groundwater survey is an important process for determining its suitability for various uses in daily human life by measurement of its physical and chemical characteristics. Present survey is done to assess and categorize the quality of groundwater of Pundri block of Kaithal district by focusing on electrical conductivity (EC), $\mathrm{pH}$, cationic and anionic composition of groundwater. According to AICRP classification, among the 98 samples collected from Pundri block, maximum samples were in good category $(60.20 \%)$ followed by alkali $(33.68 \%)$ and saline $(6.12 \%)$. All water samples in the saline group were in marginally saline category. Alkali samples were divided equally in marginally alkali, alkali and highly alkali category. Electrical conductivity of all the water samples ranged between 0.54 to $3.04 \mathrm{dSm}^{-1}$ with mean value of $2.96 \mathrm{dSm}^{-1}$. Sodium adsorption ratio in the block ranged from $4.03-11.78\left(\mathrm{mmol} \mathrm{L}^{-1}\right)^{1 / 2}$ with a mean value of $7.26\left(\mathrm{mmol}^{-1}\right)^{1 / 2}$. Observations of residual sodium carbonate were recorded in the range of nil-6.90 me $1^{-1}$ with the mean value of $1.49 \mathrm{me} \mathrm{L}^{-1}$.
\end{abstract}

\section{Introduction}

The quality of water is vital concern for mankind since it is directly linked with human health. Groundwater is highly valued because it constitutes the major drinking and irrigation water source in most of the parts of India. In recent decades, exploitation of groundwater has increased greatly, particularly for agricultural purpose, because large parts of the country have little access to rainfall due to frequent failures of monsoon. Presently, $85 \%$ of the water requirement for domestic use in rural areas, 55\% for irrigation and over 50\% for industrial and urban uses is met from groundwater (Ghosh and Sharma, 2006).
Groundwater irrigation started with only 6.5 Mha in 1950-51(CGWB, 1992), which increased to 46.5 Mha in 2000-2001 meeting about $70 \%$ of the irrigation water requirements of the country (Sivanappan, 2002).

This clearly indicates the growing pressure on groundwater resources. There is growing concern on the deterioration of groundwater quality due to geogenic and anthropogenic activities (CGWB, 2010). With the advent of green revolution, the groundwater use in agriculture has increased by a greater proportion as compared to surface water. As a result, levels have declined significantly in north-western region of the India. Moreover, 
overexploitation, excessive agriculture, untreated effluents and wastes have caused deterioration in groundwater quality. Whereas paucity of clean drinking water can affect the general health and life expectancy of people (Nash and McCall, 1995), the use of poor quality water in irrigation can degrade the soils due to contamination (Datta et al., 2000; Patel et al., 2004). Thus, the issue of availability and sustainability of safe groundwater is of great importance and calls for a scientific action plan to ensure water security in the region.

To establish water quality zones of Haryana state, efforts have been made by many researchers in the past also (Manchanda, 1976) but many areas of Haryana state are facing the problem of declining water table and quality due to exhaustive water use, shift in the cropping pattern of the state and the variable withdrawal of groundwater along with scanty rainfall (Kumar et al., 2009). So, the present study was conducted for categorizing the groundwater of Pundri block of Kaithal district and assessing the spatial variability of groundwater quality through various parameters of i.e. $\mathrm{pH}$, EC (electrical conductivity), RSC (residual sodium carbonate) and SAR (sodium adsorption ratio) according to All India Coordinated Research Project i.e. AICRP (1989).

\section{Materials and Methods}

The survey and categorization of groundwater of Pundri Block was carried out during 20152016. Pundri block comprises of 46 villages and is situated in Kaithal district of Haryana state between $29.74^{\circ}$ to $29.77^{\circ} \mathrm{N}$ latitude and $76.54^{\circ}$ to $76.57^{\circ} \mathrm{E}$ longitudes. For chemical analysis of ground water of Pundri block, total 98 water samples were taken randomly covering all the villages of the block. Samples were taken after every $2-3 \mathrm{~km}$ from running tubewells which are extensively used for irrigation purposes. The samples were analyzed for $\mathrm{EC}, \mathrm{pH}, \mathrm{CO}_{3}{ }^{2-}, \mathrm{HCO}_{3}^{-}, \mathrm{Cl}^{-}, \mathrm{SO}_{4}{ }^{2-}$, $\mathrm{Ca}^{2+}, \mathrm{Mg}^{2+}, \mathrm{Na}^{+}$and $\mathrm{K}^{+}$by following the procedures outlined in USDA Handbook No. 60 (Richards, 1954). Water samples were categorized on the basis of criteria adopted by All India Coordinated Research Project on Management of salt affected soils and use of saline water, through the values of EC, SAR and RSC of the samples (Gupta et al., 1994).

\section{Results and Discussion}

After analyzing the water samples, it was found that electrical conductivity ranged in between 0.54-3.04 $\mathrm{dSm}^{-1}$ with mean value of $2.96 \mathrm{dSm}^{-1}$ (Table 1). Sakra village recorded with minimum EC value whereas maximum EC was found in Karora village. Study revealed that $92.86 \%$ of the total water samples had EC less than $2 \mathrm{dSm}^{-1}$. Only 7 samples in the block were observed to have EC more than $2 \mathrm{dSm}^{-1}$. Location specific variability of EC in Pundri block is shown by spatial variability map in Figure 1. In the spatial variable map of EC, contours of EC values were plotted at an interval of $2 \mathrm{dSm}^{-1}$.

The $\mathrm{pH}$ of water determines whether it is acidic, neutral or alkaline in nature. All the water samples were observed with $\mathrm{pH}$ ranging from 7.01-9.40 with a mean value of 8.24 (Table 1). The $\mathrm{pH}$ was found least in village Ramana and highest in Jamba village. The spatial variability of $\mathrm{pH}$ of groundwater in Pundri block is shown in Figure 2.

Sodium adsorption ratio value of groundwater provides a useful index of the sodium hazard of the water for soils and crops. High sodium water may produce harmful levels of exchangeable sodium in most soils and requires special soil management like good drainage, high leaching and organic matter addition. 
Table.1 Range and mean of different water quality parameters of block Pundri

\begin{tabular}{|l|l|l|l|}
\hline Sr. No. & Quality Parameter & Range & Mean \\
\hline $\mathbf{1}$ & $\mathrm{pH}$ & $7.01-9.4$ & 8.20 \\
\hline $\mathbf{2}$ & $\mathrm{EC}\left(\mathrm{dSm}^{-1}\right)$ & $0.54-3.04$ & 1.28 \\
\hline $\mathbf{3}$ & $\mathrm{RSC}\left(\mathrm{me} \mathrm{L}^{-1}\right)$ & $0.00-6.90$ & 1.49 \\
\hline $\mathbf{4}$ & $\mathrm{SAR}\left(\mathrm{mmol} \mathrm{L}^{-1}\right)^{1 / 2}$ & $4.03-11.78$ & 7.26 \\
\hline $\mathbf{5}$ & $\mathrm{Ca}^{2+}\left(\mathrm{me} \mathrm{L}^{-1}\right)$ & $0.30-2.50$ & 0.81 \\
\hline $\mathbf{6}$ & $\mathrm{Mg}^{2+}\left(\mathrm{me} \mathrm{L}^{-1}\right)$ & $0.84-7.00$ & 2.32 \\
\hline $\mathbf{7}$ & $\mathrm{Na}^{+}\left(\mathrm{me} \mathrm{L}^{-1}\right)$ & $3.80-19.70$ & 8.99 \\
\hline $\mathbf{8}$ & $\mathrm{K}^{+}\left(\mathrm{me} \mathrm{L}^{-1}\right)$ & $0.07-3.14$ & 0.24 \\
\hline $\mathbf{9}$ & $\mathrm{CO}_{3}^{2-}\left(\mathrm{me} \mathrm{L}^{-1}\right)$ & $0.00-3.10$ & 1.00 \\
\hline $\mathbf{1 0}$ & $\mathrm{HCO}_{3}^{-1}\left(\mathrm{me} \mathrm{L}^{-1}\right)$ & $0.40-7.60$ & 2.76 \\
\hline $\mathbf{1 1}$ & $\mathrm{Cl}^{-}\left(\mathrm{me} \mathrm{L}^{-1}\right)$ & $1.00-20.00$ & 6.47 \\
\hline $\mathbf{1 2}$ & $\mathrm{SO}_{4}^{2-}\left(\mathrm{me} \mathrm{L}^{-1}\right)$ & $0.00-7.60$ & 1.55 \\
\hline $\mathbf{1 3}$ & $\mathrm{NO}_{3}^{-}\left(\mathrm{me} \mathrm{L}^{-1}\right)$ & $0.00-2.10$ & 0.39 \\
\hline
\end{tabular}

Table.2 Average chemical composition of water samples in different EC classes of Pundri block

\begin{tabular}{|c|c|c|c|c|c|c|c|c|c|c|c|c|c|}
\hline \multirow{2}{*}{$\begin{array}{l}\text { EC } \\
\text { Classes } \\
\left(\mathrm{dSm}^{-1}\right)\end{array}$} & \multirow{2}{*}{$\begin{array}{l}\text { No. of } \\
\text { samples }\end{array}$} & \multirow{2}{*}{$\begin{array}{l}\text { Percent } \\
\text { of } \\
\text { Samples }\end{array}$} & $\mathrm{CO}_{3}{ }^{2-}$ & $\mathrm{HCO}_{3}$ & $\mathrm{Cl}^{-}$ & $\mathrm{SO}_{4}{ }^{2-}$ & $\mathrm{NO}_{3}^{-}$ & $\mathrm{Ca}^{2+}$ & $\mathrm{Mg}^{2+}$ & $\mathrm{Na}^{+}$ & $\mathrm{K}^{+}$ & RSC & \multirow{2}{*}{$\begin{array}{l}\text { SAR } \\
(\mathrm{m} \text { mol } \\
\left.\mathrm{L}^{-1}\right)^{1 / 2}\end{array}$} \\
\hline & & & \multicolumn{10}{|c|}{$\left(m e L^{-1}\right)$} & \\
\hline $0-1$ & 29 & 29.60 & 0.37 & 1.36 & 4.20 & 1.29 & 0.15 & 0.51 & 1.44 & 5.69 & 0.16 & 0.42 & 5.82 \\
\hline $1-2$ & 62 & 63.30 & 1.37 & 3.51 & 6.23 & 1.35 & 0.65 & 0.80 & 2.32 & 9.71 & 0.20 & 2.25 & 7.89 \\
\hline$\geq 2$ & 7 & 7.14 & 0.77 & 2.04 & 15.96 & 4.27 & 0.20 & 1.93 & 5.42 & 15.90 & 0.67 & 0.06 & 8.33 \\
\hline
\end{tabular}

Table.3 Ground water quality classification of Pundri block

\begin{tabular}{|l|l|c|c|} 
Water quality & Class & $\begin{array}{c}\text { Number of } \\
\text { samples }\end{array}$ & Percentage \\
\hline Good & A & 59 & 60.20 \\
\hline Saline & B & & 6.12 \\
\hline $\begin{array}{l}\text { Marginally } \\
\text { Saline }\end{array}$ & B1 & 6 & 0 \\
\hline Saline & B2 & 0 & 0 \\
\hline High SAR Saline & B3 & 0 & 11.23 \\
\hline Alkali Water & C & 11 & 11.23 \\
\hline $\begin{array}{l}\text { Marginally } \\
\text { Alkali }\end{array}$ & C1 & & 11.23 \\
\hline Alkali & C2 & 11 & \\
\hline Highly alkali & C3 & 11 & \\
\hline Total & & 98 &
\end{tabular}


Fig.1 Spatial variability of EC of groundwater in Pundri block

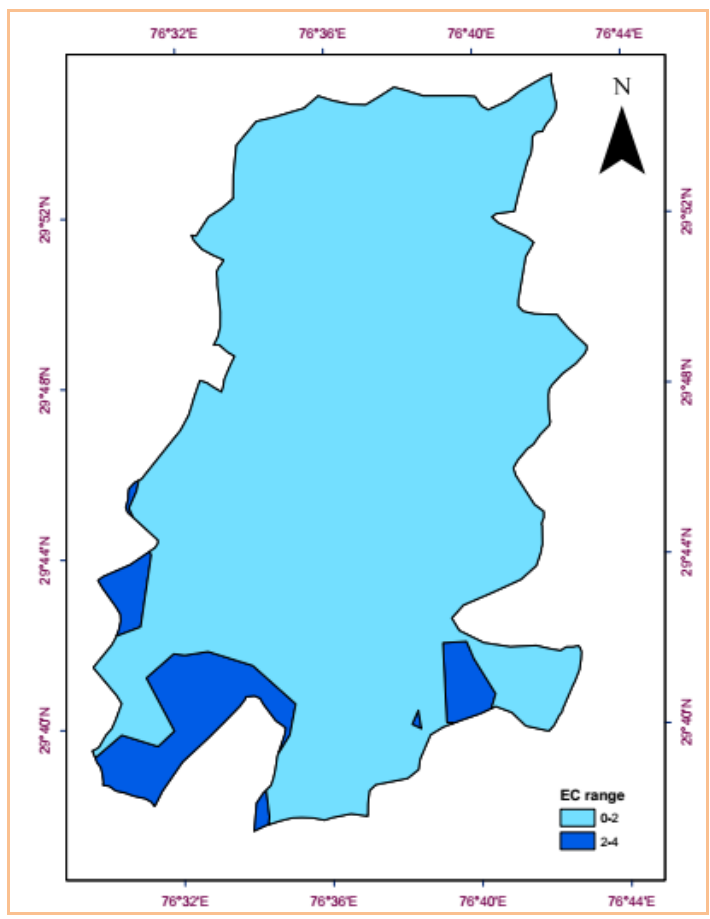

Fig.2 Spatial variability of $\mathrm{pH}$ of groundwater in Pundri block

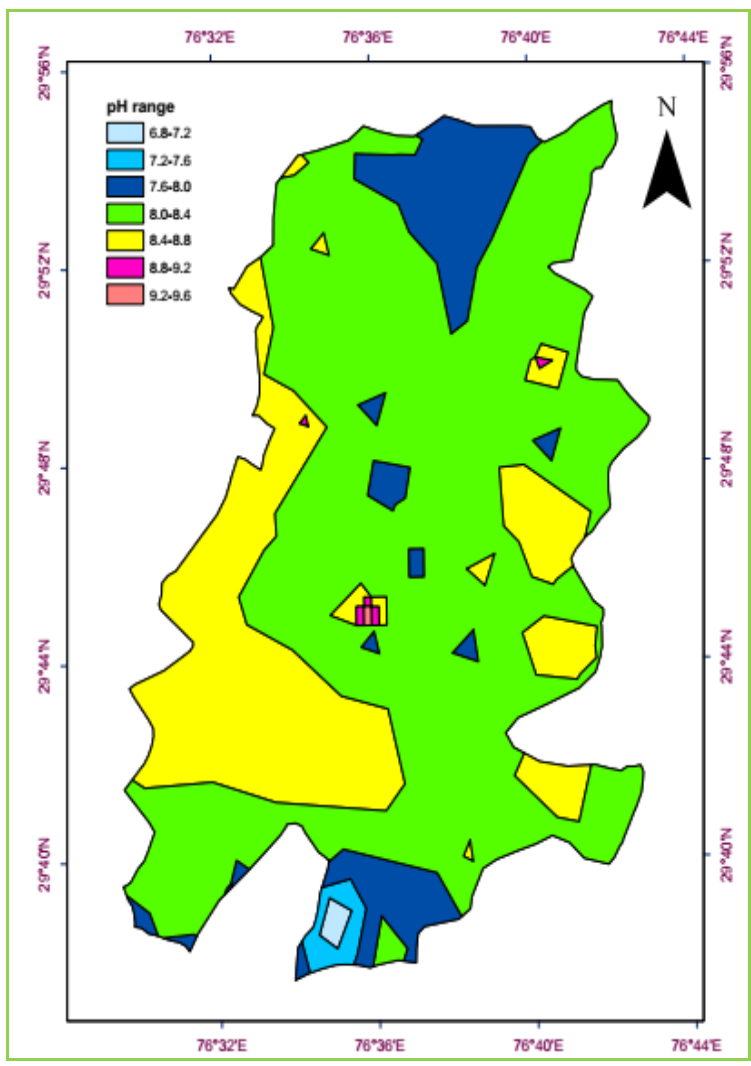


Fig.3 Spatial variability of SAR of groundwater in Pundri block

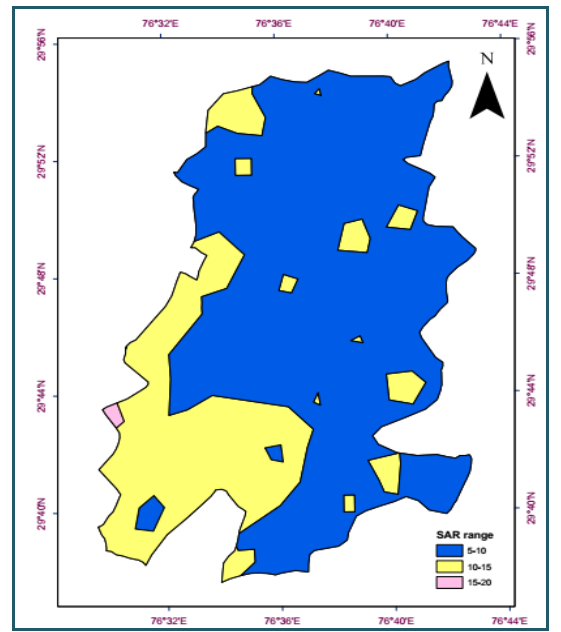

Fig.4 Spatial variability of RSC of groundwater in Pundri block

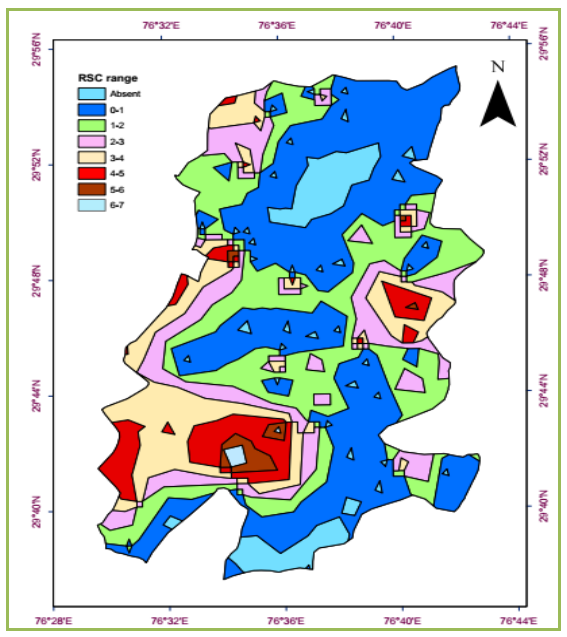

Fig.5 Quality of groundwater (percent) in Pundri block

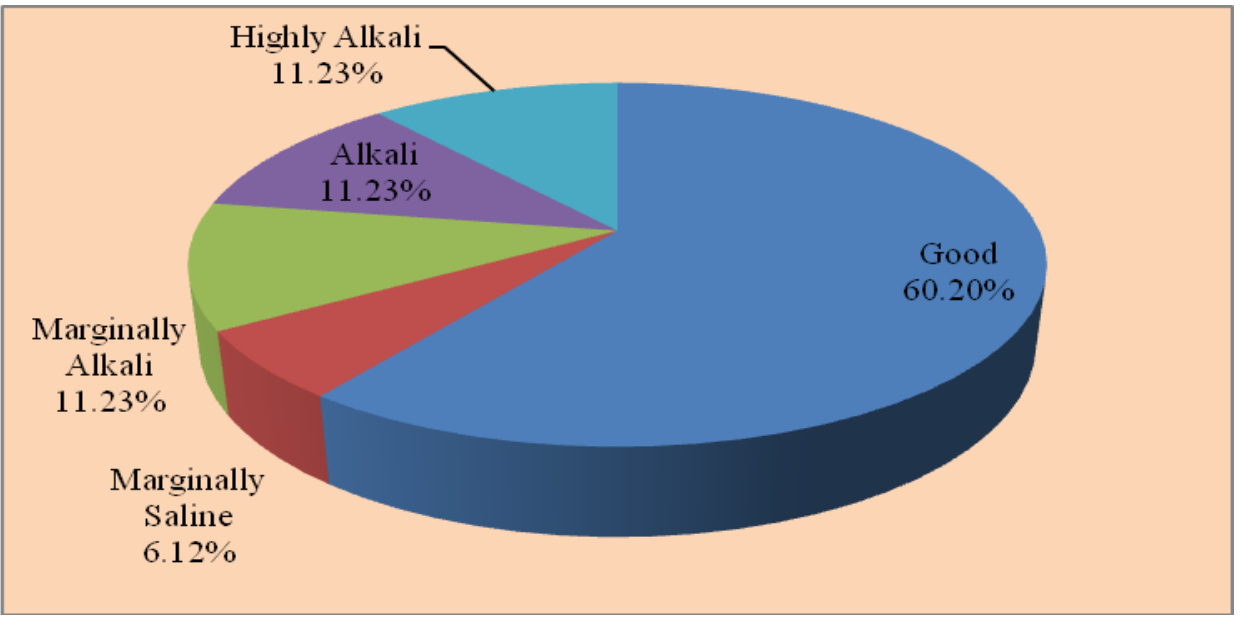


Fig.6 Spatial variability of groundwater quality of Pundri block

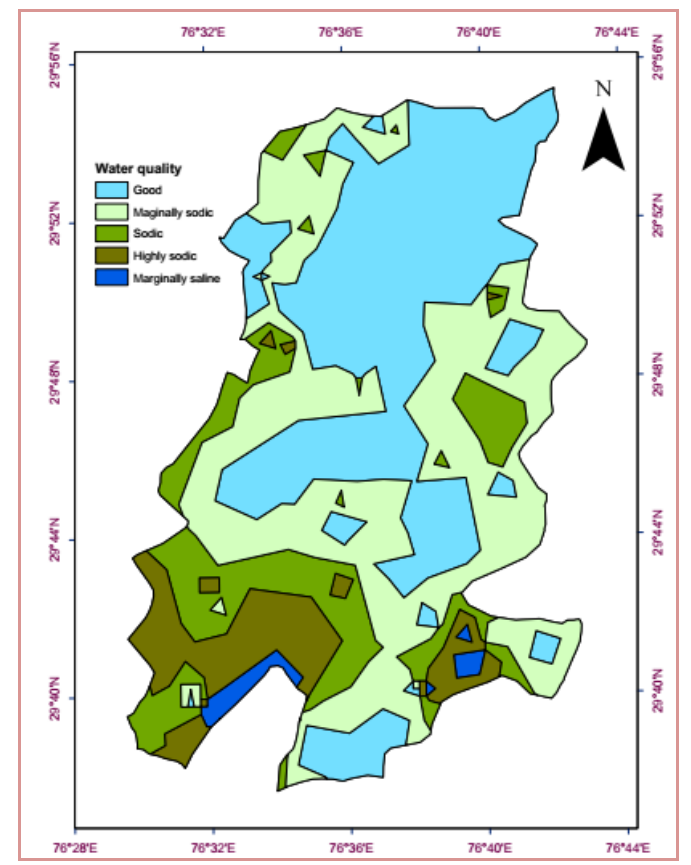

SAR in the block ranged from 4.03-11.78 $\left(\mathrm{mmol} \mathrm{L} \mathrm{L}^{-1}\right)^{1 / 2}$ with a mean value of 7.26 $\left.(\mathrm{mmol} \mathrm{L})^{-1}\right)^{1 / 2}$ (Table 1). The lowest SAR was observed in village Chuharmajra and highest in Ramana village. Most of the part of block have SAR in range of 5-10 $\left(\mathrm{mmol} \mathrm{L}^{-1}\right)^{1 / 2}$ and in some parts of block it was found in between $\quad 15-20 \quad\left(\mathrm{mmol} \quad \mathrm{L}^{-1}\right)^{1 / 2}$.Spatial variability of SAR within the block is shown in Figure 3. Observations of residual sodium carbonate were found in the range of nil-6.90 me $\mathrm{L}^{-1}$ with the mean value of $1.49 \mathrm{me}^{-1}$. The maximum RSC was found in village Hajwana and minimum value was observed in village Ramana. Taking residual sodium carbonate as the index for assessing groundwater quality, no uniformity was observed in the samples collected from different areas of block as shown in spatial variability map in Figure 4.

In case of cations, sodium was the dominant cation and its concentration varied from 3.80$19.70 \mathrm{me} \mathrm{L}^{-1}$, with minimum value observed in Sakra village and maximum in Karora village followed by magnesium $(0.84-7.00 \mathrm{me}$ $\left.\mathrm{L}^{-1}\right)$, calcium $\left(0.30-2.50\right.$ me $\left.\mathrm{L}^{-1}\right)$ and potassium (0.07-3.14 me $\left.\mathrm{L}^{-1}\right)$. Average value for $\mathrm{Na}^{+}, \mathrm{Mg}^{2+,} \mathrm{Ca}^{2+}$ and $\mathrm{K}^{+}$were $8.99,2.32$, 0.81 and $0.24 \mathrm{me} \mathrm{L}^{-1}$, respectively (Table 1 ). The cations in groundwater were found in order of $\mathrm{Na}^{+}>\mathrm{Mg}^{2+}>\mathrm{Ca}^{2+}>\mathrm{K}^{+}$. In case of anions, chloride was the dominant anion with maximum concentration of $20.00 \mathrm{me} \mathrm{L}^{-1}$ in village Karora and minimum in Jamba village, followed by bicarbonate (0.40-7.60 me $\left.\mathrm{L}^{-1}\right)$, sulphate $\left(0.00-7.60\right.$ me $\left.\mathrm{L}^{-1}\right)$, carbonate $\left(0.00-3.10 \mathrm{me} \mathrm{L}^{-1}\right)$ and nitrate (0.00-2.10 $\left.\mathrm{me} \mathrm{L}^{-1}\right)$. Average value for $\mathrm{CO}_{3}^{2-}$, $\mathrm{HCO}_{3}{ }^{-}, \mathrm{Cl}^{-}, \mathrm{SO}_{4}{ }^{2-}$ and $\mathrm{NO}_{3}{ }^{-} 1.00,2.76,6.47$, 1.55 and $0.39 \mathrm{me} \mathrm{L}^{-1}$, respectively (Table 1 ) and anions were found in order of $\mathrm{Cl}^{-}>\mathrm{HCO}_{3}{ }^{-}$ $>\mathrm{SO}_{4}{ }^{2-}>\mathrm{CO}_{3}{ }^{2-}>\mathrm{NO}_{3}{ }^{-}$.In arid and semi-arid regions, various workers have reported the dominance of sodium and chloride ions in irrigation waters (Sharma, 1998; Shahid et al., 2008; Ramprakash et al., 2013; Rajpaul et al., 2014; Sanjay et al., 2016). Average of chemical composition and related quality parameters in different EC ranges for Pundri block is given in Table 2. Maximum percent $(63.30 \%)$ of samples were found in the EC range of 1-2 $\mathrm{dSm}^{-1}$. Concentration of $\mathrm{Na}^{+}$, 
$\mathrm{Mg}^{2+}, \mathrm{Ca}^{2+}$ and $\mathrm{K}^{+}$increased with increase in the EC of the water samples and the magnitude of increase in $\mathrm{Na}^{+}$and $\mathrm{Mg}^{2+}$ concentration was much higher than $\mathrm{Ca}^{2+}$. Similarly, concentration of $\mathrm{Cl}^{-}$and $\mathrm{SO}_{4}{ }^{2-}$ increased with the increase in the $\mathrm{EC}$ of the water samples. $\mathrm{HCO}_{3}{ }^{-}$and $\mathrm{CO}_{3}{ }^{2-}$ were also found to be in appreciable quantities whereas $\mathrm{NO}_{3}{ }^{-}$was recorded in low quantity and their concentration did not show any relation with EC of groundwater.

Depending on the concentration of EC, SAR and RSC water samples were classified into different categories as per the classification of All India Coordinated Research Project (AICRP1989) on "Management of salt affected soils and use of saline water in agriculture". According to this classification, among the 98 samples collected from Pundri block, maximum samples were in good category $(60.20 \%)$ followed by alkali $(33.68 \%)$ and saline $(6.12 \%)$ as presented in Table 3. Distribution of different categories of water samples is shown quality is shown in pie chart Figure 5. The Spatial variability of water quality of groundwater in Pundri block is presented in and Figure 6. In the saline group all water samples $(6.12 \%)$ were found in marginally saline category. Out of the total samples, $33.68 \%$ were in alkali group, which were divided equally in marginally alkali, alkali and highly alkali category. Out of seven categories of water, maximum (60.20\%) samples were found in good category and minimum $(6.12 \%)$ in saline category.

Among the 98 samples collected from Pundri block, maximum samples were in good category $(60.20 \%)$ followed by alkali (33.68\%) and saline (6.12\%). Graphical maps prepared by using GPS can be used for monitoring the degraded lands. Spatial maps of various chemical parameters can be used for improving the groundwater quality in the area. Saline and alkali water should be used in combination with good quality water for irrigating the crops to improve the soil. Also, the proper soil water management strategies can help in maintaining adequate salt-water balance for better crop cultivation.

\section{References}

CGWB. 1992. Groundwater. In: Proceedings of 3rd National Water Commission, Nagpur, India, Central Ground Water Board, Govt. of India.

CGWB. 2010. Groundwater quality in shallow aquifers of India, Faridabad, Central Groundwater Board, Ministry of Water Resources, Govt. of India.

Datta, S.P., Biswas, D.R., Saharan, N., Ghosh, S.K. and Rattan, R. K., 2000. Effect of long-term application of sewage effluents on organic carbon, bio-available phosphorus, potassium and heavy metals status of soil and uptake of heavy metals by crops. J. Ind. Soc. Soil Sci. 48: 836-839.

Ghosh, N.C. and Sharma, K.D. 2006. Groundwater modeling and management, New Delhi.

Gupta, R.K., Singh, N.T. and Sethi, M. 1994. Water quality for irrigation in India. Tech. Bulletin No.19, CSSRI, Karnal, India.

Kumar, S., Phogat, V., Satyavan, Kaushik, R.D. and Sharma, S.K. 2009.Assessment of ground water quality for irrigation of Adampur block, Hisar, Haryana. Environ. Ecol. 27(2A): 857-859.

Manchanda, H.R. 1976. Quality of underground water of Haryana. Tech. Bulletin, Haryana Agricultural University, Hisar.

Nash, H. and McCall, G.J. H. 1995. (eds.). Groundwater quality. In: 17th Special Report, Chapman and Hall, London. Marechal, J.C., Dewandel, B., Ahmed, S., Galeazzi, L. and Zaidi, F. K. 2006. 
Combined estimation of specific yield and natural recharge in a semi-arid groundwater basin with irrigated agriculture. J. Hydrol. 329: 281-293.

Patel, K. P., Pandya, R.R., Maliwal, G.L., Patel, K.C., Ramani, V. P. and George, V. 2004. Heavy metal content of different effluents and their relative availability in soils irrigated with effluent waters around major industrial cities of Gujarat, J. Ind. Soc. Soil Sci. 52: 89-94.

Rajpaul, Ramprakash., Kumar. S., Sharma, S.K. and Satyavan. 2014. Spatial variability of groundwater quality in irrigated agriculture Salhawas block of Jhajjar district (Haryana). Annals Biol. 30(3): 460-463.

Ramprakash., Kumar. S., Rajpaul, Sharma, S.K. and Satyavan. 2013. Mapping of groundwater quality of Beri block of Jhajjar district in Haryana. J. Soil Salinity and Water Quality. 13(2): 134139.

Richards, L.A. 1954. Diagnosis and improvement of saline and alkali soils. U.S.D.A. Hand Book No. 60. Oxford and IBH Publishing Co., New Delhi.

Sanjay, K., Sharma, S.K., Ramprakash, Rajpaul and Satyavan. 2016. Spatial variation of groundwater quality of Meham Block of Rohtak District, Haryana. Ind. J. Soil Cons. 44(2): 163167.

Shahid, M., Singh, A.P., Bhandari, D.K. and Ahmad, I. 2008. Groundwater quality appraisal and categorization in Julana block of Jind district, Haryana. J. Ind. Soc. Soil Sci. 56(1): 123-125.

Sharma, D.R. 1998. Assessment of the nature and extent of poor quality of underground water resources. In: National Seminar on "Strategies for the Management of Poor Quality Water in Agriculture", CSSRI, Karnal. pp. 4-5.

Sivanappan, R. K. 2002.Expansion of storage capacity, critical. In: Ravi. $\mathrm{N}$ (ed), Survey of Indian Agriculture. The Hindu, India.

\section{How to cite this article:}

Parveen Rathi, Ramprakash, Sanjay Kumar, Satyavan and Raman Sharma. 2018. Spatial Variability in Groundwater Quality in Pundri block of Kaithal District, Haryana. Int.J.Curr.Microbiol.App.Sci. 7(02): 1262-1269. doi: https://doi.org/10.20546/ijcmas.2018.702.154 